\title{
Cyclooxygenase/lipoxygenase shunting lowers the anti-cancer effect of cyclooxygenase-2 inhibition in colorectal cancer cells
}

\author{
Radhakrishnan Ganesh ${ }^{1 *}$, Daniel JB Marks ${ }^{2}$, Kevin Sales$^{1}$, Marc C Winslet ${ }^{1}$ and Alexander M Seifalian ${ }^{1}$
}

\begin{abstract}
Background: Arachidonic acid metabolite, generated by cyclooxygenase (COX), is implicated in the colorectal cancer (CRC) pathogenesis. Inhibiting COX may therefore have anti-carcinogenic effects. Results from use of non-steroidal anti-inflammatory drugs inhibiting only COX have been conflicting. It has been postulated that this might result from the shunting of arachidonic acid metabolism to the 5-lipoxygenase (5-LOX) pathway. Cancer cell viability is promoted by 5-LOX through several mechanisms that are similar to those of cyclooxygenase-2 (COX-2). Expression of 5-LOX is upregulated in colorectal adenoma and cancer. The aim of this study was to investigate the shunting of arachidonic acid metabolism to the 5-LOX pathway by cyclooxygenase inhibition and to determine if this process antagonizes the anti-cancer effect in colorectal cancer cells.

Methods: Three colorectal cancer cell lines (HCA7, HT-29 \& LoVo) expressing 5-LOX and different levels of COX-2 expression were used. The effects of aspirin (a non-selective COX inhibitor) and rofecoxib (COX-2 selective) on prostaglandin $E_{2}\left(P_{G} E_{2}\right)$ and leukotriene $B_{4}\left(L_{T B}\right)$ secretion were quantified by ELISA. Proliferation and viability were studied by quantifying double-stranded DNA (dsDNA) content and metabolic activity. Apoptosis was determined by annexin $V$ and propidium iodide staining using confocal microscopy, and caspase-3/7 activity by fluorescent substrate assay.
\end{abstract}

Results: COX inhibitors suppressed $\mathrm{PGE}_{2}$ production but enhanced $\mathrm{LTB}_{4}$ secretion in COX-2 expressing cell lines $(P<0.001)$. The level of COX-2 expression in colorectal cancer cells did not significantly influence the anti-proliferative and pro-apoptotic effects of COX inhibitors due to the shunting mechanism.

Conclusions: This study provides evidence of shunting between COX and 5-LOX pathways in the presence of unilateral inhibition, and may explain the conflicting anti-carcinogenic effects reported with use of COX inhibitors.

Keywords: Apoptosis, Colorectal cancer, Cyclooxygenase, Eicosanoids, Lipoxygenase

\section{Background}

Colorectal cancer (CRC) remains a leading cause of cancer death, with highest incidence in westernized populations. The pathogenic sequence is well-understood, with characteristic genetic and biochemical abnormalities underlying the adenoma-carcinoma progression [1]. The long phase of progressive premalignant lesions, coupled with the availability of appropriate investigations, provides an opportunity for intervention and primary

\footnotetext{
* Correspondence: ganeshr26@yahoo.co.uk

${ }^{1}$ Division of Surgery and Interventional Science, University College London, Rowland Hill Street, London NW3 2PF, UK

Full list of author information is available at the end of the article
}

prevention. A number of chemopreventative strategies have been postulated. There is substantial evidence that diet modifies risk, $[2,3]$ and oral agents that show promise include folate, statins, calcium, ursodeoxycholic acid and cyclooxygenase (COX) inhibitors [4-7].

Metabolites of arachidonic acid (AA) are important mediators in the adenoma-carcinoma sequence [8-10]. COX and 5-lipoxygenase (5-LOX) are the key enzymes involved in the generation of prostaglandins and leukotrienes respectively from this precursor. These were originally identified as playing important roles in the modulation of inflammation. Cyclooxygenase has two isoforms: COX-1 and COX-2. The former is constitutively 
expressed in most tissues, whereas the latter is an immediate-to-early response gene [11]. It is undetectable in most normal tissues, but is upregulated in colorectal neoplasms and their precursor lesions, [12] in which levels of downstream prostaglandin $\mathrm{E}_{2}\left(\mathrm{PGE}_{2}\right)$ are also elevated [13]. Genetic manipulation studies have shown a causal role for COX-2 in carcinogenesis in cytological and animal models [14-16]. Inhibition of COX-2 activity reverses CRC carcinogenesis in these systems, [17] and has been shown to induce apoptosis, and inhibit proliferation and angiogenesis $[18,19]$. Similar data have also recently emerged for 5-LOX [20,21]. Expression of 5-LOX has been demonstrated in some cancer cells and is involved in the pathogenesis of cancer. Interestingly, 5-LOX appears to have similar mechanisms to COX-2 in the regulation of cell viability, although these two enzymes often utilize different signaling pathways. Furthermore, it was suggested that arachidonic acid might be shunted from one pathway to the other when a particular pathway is inhibited in the cellular processes of cancer [22] and inflammation [23].

COX inhibitors are potentially attractive drugs for the chemoprevention of colorectal cancer, and have been reported to induce regression of polyps in patients with familial adenomatous polyposis [24]. Observational studies suggest a protective effect of non-steroidal anti-inflammatory drugs (NSAIDs), [25] which nonspecifically inhibit COX-2 and its isoform COX-1. Use of these agents is, however, unfortunately limited by gastrointestinal and renal side-effects [26]. Specific COX-2 inhibitors were developed to circumvent these issues, although reports suggest that they are associated with significant cardiovascular adverse effects [27].

Studies evaluating anti-carcinogenic properties of COX-2 inhibitors however have not shown consistent results. There is a mismatch between the growthsuppressing effect of COX-2 inhibitors $[28,29]$ and procarcinogenic effect of prostaglandins [30]. It is possible that the shunting of AA between COX-2 and 5-LOX that utilize AA will bypass COX-2 inhibition. In cells expressing both enzymes, inhibition of one in isolation may shunt metabolism preferentially down the other pathway, leading to paradoxically increased production of selected eicosanoids. In the presence of COX-2 and 5-LOX expression in cancer cells, combined inhibition of these pathways would likely to be a more effective anti-cancer modality with fewer side-effects.

Here we investigated the effects of NSAIDs on eicosanoid production from colorectal cancer cell lines expressing different level of COX-2 and its consequent anti-neoplastic effects. In this study, we hypothesized that in the presence of shunting between COX-2 and 5-LOX pathway, COX-2 inhibition might fail to show anti-cancer effect irrespective of COX-2 expression.
Thus shunting of AA between COX-2 and 5-LOX pathways that utilize AA may bypass COX-2 inhibition.

\section{Methods}

\section{Cell lines}

Three human colon adenocarcinoma cell lines (HCA-7, HT29 and LoVo) were studied in vitro (European Collection of Cell Cultures, Salisbury, UK). HCA-7 expresses functional COX-2, and was cultured in Dulbecco's Modified Eagle Medium (DMEM) with L-glutamine (Sigma, Gillingham, UK). HT29 expresses an enzymatically inactive COX-2 isoform [31], and was cultured in McCoy's 5A medium (Sigma). LoVo is derived from a metastatic adenocarcinoma not expressing COX-2, and was grown in Ham's F-12 medium with L-glutamine (Sigma). Media were supplemented with $10 \%$ fetal bovine serum, penicillin and streptomycin (2\%). Cells were incubated at $37^{\circ} \mathrm{C}$ in $5 \%$ $\mathrm{CO}_{2}$, grown to $90 \%$ confluence in $75 \mathrm{~cm}^{2}$ flasks, and trypsinized and plated for experiments as described below.

Following overnight incubation, medium was exchanged for that containing test reagent. Rofecoxib (Merck, Nottingham, UK) was dissolved in DMSO to a stock concentration of $100 \mathrm{mM}$ and was then diluted in medium to the final concentrations. Aspirin (Sigma) was dissolved in $1 \mathrm{M}$ Tris- $\mathrm{HCl}$ to a stock concentration of $1 \mathrm{M}$ with $\mathrm{pH}$ adjusted to 7 . Negative controls were the equivalent media containing no drug.

\section{Eicosanoid production}

$\mathrm{PGE}_{2}$ and leukotriene $\mathrm{B}_{4}\left(\mathrm{LTB}_{4}\right)$ secretion were quantified by ELISA (Cayman Chemicals, Tallinn, Estonia) as previously described [32]. Cells $\left(1 \times 10^{5}\right)$ were plated overnight in $25 \mathrm{~cm}^{2}$ flasks and were then treated with the test reagents for 4 hours in serum-free medium. Supernatants were assayed and concentrations normalized to the number of adherent cells in the sample culture.

\section{Proliferation}

Cells were grown in $25 \mathrm{~cm}^{2}$ flasks at a concentration of $1 \times 10^{5}$ cells $/ \mathrm{ml}$, treated for 24,48 or 72 hours, and were then trypsinized and centrifuged into pellets. These were homogenized using a 25 gauge needle to release DNA, which was measured using the Picogreen ${ }^{\mathrm{TM}}$; dsDNA Assay kit (Invitrogen, Paisley, UK) as previously described [33]. We used this assay to quantify doublestranded DNA using a fluorescence readout (excitation: $485 \mathrm{~nm}$, emission: $538 \mathrm{~nm}$ ) on a Fluroskan Ascent FL spectrofluorometer (Thermo Life Sciences, Basingstoke, UK). Reduction in proliferation is expressed as a percentage of the appropriate control.

\section{Viability}

Viability was assessed by alamar blue (Serotec, Oxfordshire, UK) reduction, which provides a colorimetric readout of 
the reducing environment of proliferating cells. Cells were plated in 24-well plates at a concentration of $1 \times 10^{4}$ cells/ml, and treated for 24,48 or 72 hours; viability at baseline was $>95 \%$. After treatment, medium was exchanged for that containing 10\% alamar blue. After 4 hours, $100 \mu \mathrm{L}$ of supernatant was transferred to a 96well plate and read in a fluorescence plate reader (excitation: $560 \mathrm{~nm}$, emission: $590 \mathrm{~nm}$ ). Viability following drug treatment was compared to the appropriate control and expressed as a percentage.

\section{Apoptosis}

Apoptosis was quantified by annexin- $\mathrm{V}$ and propidium iodide staining, using Annexin V-FITC apoptosis detection assay kit (Calbiochem, Nottingham, UK). Cells were plated in six-well plates at a concentration of $1 \times 10^{5}$ cells $/ \mathrm{ml}$, and treated for 24,48 and 72 hours, washed with phosphate-buffered saline (PBS) and treated with assay buffer, Annexin-FITC and propidium iodide as per the protocol described by the manufacturer. Apoptotic cells were detected under fluorescence microscopy, with early apoptotic cells exposing phosphatidyl serine at the cell wall and appearing green on the cell membrane surface and late apoptotic cells staining red throughout the cytoplasm. Apoptosis in each group was quantified as the percentage of apoptotic cells per high power field.

\section{Caspase-3/7 activity}

The enzymatic activity of caspase-3/7 was measured using a commercially available fluorescent assay, according to the instructions from the manufacturer. Cells were grown in 96-well plates at a concentration of $1 \times 10^{3}$ cells/well, and treated with test drugs for $12,24,48$ or 72 hours. After treatment the level of caspase activity was measured using the Apo-ONE ${ }^{\circledR}$ homogenous caspase-3/7 assay (Promega, Southampton, UK), which employs a profluorescent caspase-3/7 substrate that once activated can be detected using a fluorescence plate reader (excitation: $499 \mathrm{~nm}$, emission: $521 \mathrm{~nm}$ ).

\section{Statistical analysis}

All experiments were repeated a minimum of three times. Statistical analyses were conducted using GraphPad Prism v4.1 (GraphPad Software, La Jolla, CA, USA) using a two-way Analysis of Variance (ANOVA) with Bonferroni post-test correction. A $P$ value $<0.05$ was considered significant.

\section{Results}

\section{Eicosanoid production}

$\mathrm{PGE}_{2}$ production was assayed as a biologically relevant indicator of functional COX-2 activity. Consistent with the level of COX-2 expression in each cell type, HCA7
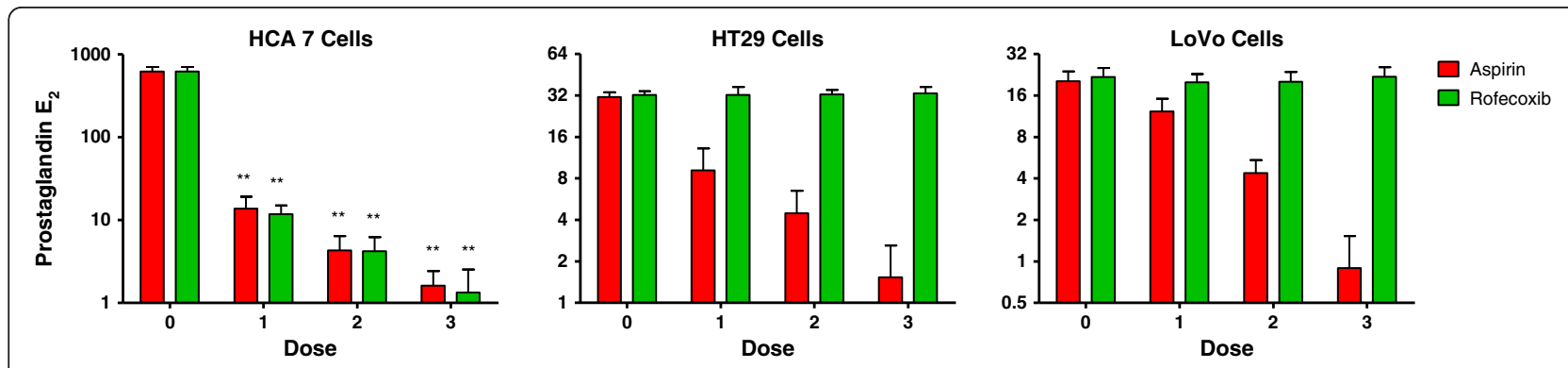

A Prostaglandin $\mathrm{E}_{2}$ measured by ELISA
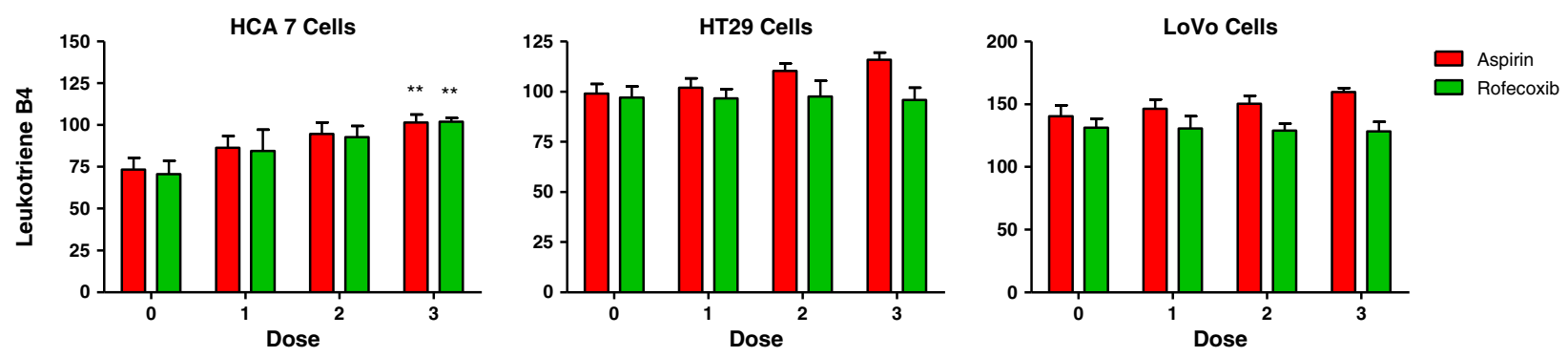

\section{$\mathrm{B}$ Leukotriene $\mathrm{B}_{4}$ measured by ELISA}

Figure 1 Effect of aspirin and rofecoxib on (A) prostaglandin $E_{2}$ and (B) leukotriene $B 4$ secretion by different cell lines. Cells were cultured without agents (dose 0); with $1 \mu \mathrm{M}$ rofecoxib, $10 \mu \mathrm{M}$ aspirin (dose 1); $10 \mu \mathrm{M}$ rofecoxib, $100 \mu \mathrm{M}$ aspirin (dose 2); or $100 \mu \mathrm{M}$ rofecoxib, $1,000 \mu \mathrm{M}$ aspirin (dose 3). Mean and standard deviations of triplicate cultures shown. $\left({ }^{* *} P<0.001\right)\left({ }^{* *}=P<0.001\right)$. 
cells produced the highest concentrations. HT29 cells express an inactive isoform, and LoVo cells do not express $\mathrm{COX}-2 ; \mathrm{PGE}_{2}$ release was minimal from these cells. Treatment with aspirin was associated with concentrationdependent reduction in $\mathrm{PGE}_{2}$ levels in all cell lines $(P<0.001)$. Rofecoxib, as a specific COX-2 inhibitor, reduced $\mathrm{PGE}_{2}$ production only in $\mathrm{HCA} 7$ cells (Figure 1A).

$\mathrm{LTB}_{4}$ was produced by all cells. Aspirin caused a significant increase in production from $\mathrm{HCA} 7$ cells $(P<0.001)$ and a moderate increase in HT29 and LoVo cells that was not significant. Rofecoxib caused a significant increase in $\mathrm{LTB}_{4}$ production in $\mathrm{HCA} 7$ cells $(P<0.001)$ but did not cause a significant amount of production in other cell lines. (Figure $1 \mathrm{~B}$ ) $\mathrm{LTB}_{4}$ was produced by all cells but treatment with aspirin and rofecoxib either increased its production or did not alter its production dependent on cell line.

\section{Proliferation}

We subsequently determined the ability of the test agents to inhibit cellular proliferation. Within 24 hours there was less than $5 \%$ reduction in proliferation by aspirin and rofecoxib. Aspirin caused significant inhibition of proliferation only after 72 hours at $1 \mathrm{mM}$ dose $(P<0.05)$. Rofecoxib did not significantly affect proliferation in any cell line (Table 1). There were no significant differences in the inhibitory capacities between cell lines.

The assay used to examine proliferation is indirect in that it measures absolute numbers of cells. We therefore tested whether the decreased proliferative potential was due to reduced viability. Aspirin reduced viability by less than $10 \%$ in all cell lines at the higher dose used and was only significant at 72 hours at the $1 \mathrm{mM}$ dose
$(P<0.05)$. Rofecoxib did not affect viability significantly in any cell line tested (Figure 2).

\section{Apoptosis}

Chemopreventative properties of agents often correlate with the degree of induction of apoptosis, which appears to provide a reliable biomarker for the evaluation of potential novel therapeutic agents. We quantified the number of apoptotic cells using Annexin-V/propidium iodide staining. Annexin- $\mathrm{V}$ binds phosphatidyl serine that is externalized to the cell surface with the loss of membrane integrity occurring during the early stages of apoptosis. Propidium iodide differentiates late apoptotic and necrotic cells as it can only permeate cells during these stages (Figure 3A). Aspirin did not induce significant apoptosis for up to 48 hours in all cell lines. Aspirin at $1 \mathrm{mM}$ caused significant apoptosis only at 72 hours of treatment $(P<0.05)$, and rofecoxib had no apoptotic effect in all cell lines (Figure 3B).

Caspase induction is the final common pathway in the various apoptotic signaling cascades. It is activated in advance of any morphological changes of apoptosis. Caspase activity was induced to a significant level by aspirin at $1 \mathrm{mM}$ after 48 hours of treatment in all cell lines and its activity declined at 72 hours. Aspirin at lower dose and rofecoxib failed to induce significant caspase activity in all cell lines (Figure 3C).

\section{Discussion}

Aberrant arachidonic acid metabolism is implicated in CRC carcinogenesis [34]. Manipulation of these pathways offers novel therapeutic strategies to prevent or reverse neoplasia. COX and 5-LOX are the two important

Table 1 Effects of aspirin and rofecoxib on cellular proliferation, expressed as reduction relative to control

\begin{tabular}{|c|c|c|c|c|c|c|c|}
\hline \multirow[t]{2}{*}{$24 \mathrm{~h}$} & \multirow[t]{2}{*}{ Dose } & \multicolumn{2}{|c|}{ HCA7 } & \multicolumn{2}{|c|}{ НT29 } & \multicolumn{2}{|c|}{ LoVo } \\
\hline & & aspirin & rofecoxib & aspirin & rofecoxib & aspirin & rofecoxib \\
\hline & A & $2.0 \pm 1.3$ & $1.7 \pm 1.4$ & $1.2 \pm 0.9$ & $1.3 \pm 0.9$ & $1.0 \pm 0.3$ & $0.9 \pm 0.5$ \\
\hline & $B$ & $2.9 \pm 1.9$ & $1.6 \pm 0.6$ & $1.9 \pm 1.3$ & $1.1 \pm 0.2$ & $1.5 \pm 0.6$ & $1.7 \pm 1.3$ \\
\hline & C & $2.4 \pm 1.1$ & $2.2 \pm 0.8$ & $1.7 \pm 0.7$ & $1.8 \pm 0.8$ & $1.5 \pm 0.6$ & $1.8 \pm 1.0$ \\
\hline \multirow[t]{5}{*}{$48 \mathrm{~h}$} & Dose & \multicolumn{2}{|c|}{ HCA7 } & \multicolumn{2}{|c|}{ HT29 } & \multicolumn{2}{|c|}{ LoVo } \\
\hline & & aspirin & rofecoxib & aspirin & rofecoxib & aspirin & rofecoxib \\
\hline & A & $2.3 \pm 1.2$ & $2.3 \pm 1.4$ & $2.0 \pm 0.9$ & $1.5 \pm 0.6$ & $1.8 \pm 0.6$ & $1.4 \pm 0.8$ \\
\hline & $B$ & $3.6 \pm 1.8$ & $2.5 \pm 0.8$ & $2.6 \pm 1.7$ & $2.2 \pm 1.0$ & $2.7 \pm 1.2$ & $2.4 \pm 1.3$ \\
\hline & C & $6.0 \pm 2.7$ & $3.8 \pm 1.4$ & $3.7 \pm 1.7$ & $2.4 \pm 1.4$ & $2.7 \pm 1.2$ & $2.7 \pm 0.9$ \\
\hline \multirow[t]{5}{*}{$72 \mathrm{~h}$} & Dose & \multicolumn{2}{|c|}{ HCA7 } & \multicolumn{2}{|c|}{ HT29 } & \multicolumn{2}{|c|}{ LoVo } \\
\hline & & aspirin & rofecoxib & aspirin & rofecoxib & aspirin & rofecoxib \\
\hline & A & $4.6 \pm 1.7$ & $2.9 \pm 1.6$ & $3.4 \pm 1.6$ & $3.0 \pm 1.8$ & $2.5 \pm 1.0$ & $2.4 \pm 0.8$ \\
\hline & $B$ & $5.0 \pm 1.6$ & $3.5 \pm 2.0$ & $4.8 \pm 2.3$ & $2.9 \pm 1.4$ & $2.8 \pm 0.9$ & $2.3 \pm 1.0$ \\
\hline & C & $7.7 \pm 1.9$ & $4.0 \pm 1.6$ & $6.5 \pm 2.0$ & $4.1 \pm 1.8$ & $5.3 \pm 1.8$ & $2.9 \pm 1.6$ \\
\hline
\end{tabular}

The cells were cultured with $1 \mu \mathrm{M}$ rofecoxib, $10 \mu \mathrm{M}$ aspirin (dose $\mathrm{A}$ ); $10 \mu \mathrm{M}$ rofecoxib, $100 \mu \mathrm{M}$ aspirin (dose $\mathrm{B}$ ); or $100 \mu \mathrm{M}$ rofecoxib, $1,000 \mu \mathrm{M}$ aspirin (dose C). Mean and standard deviations are shown. 


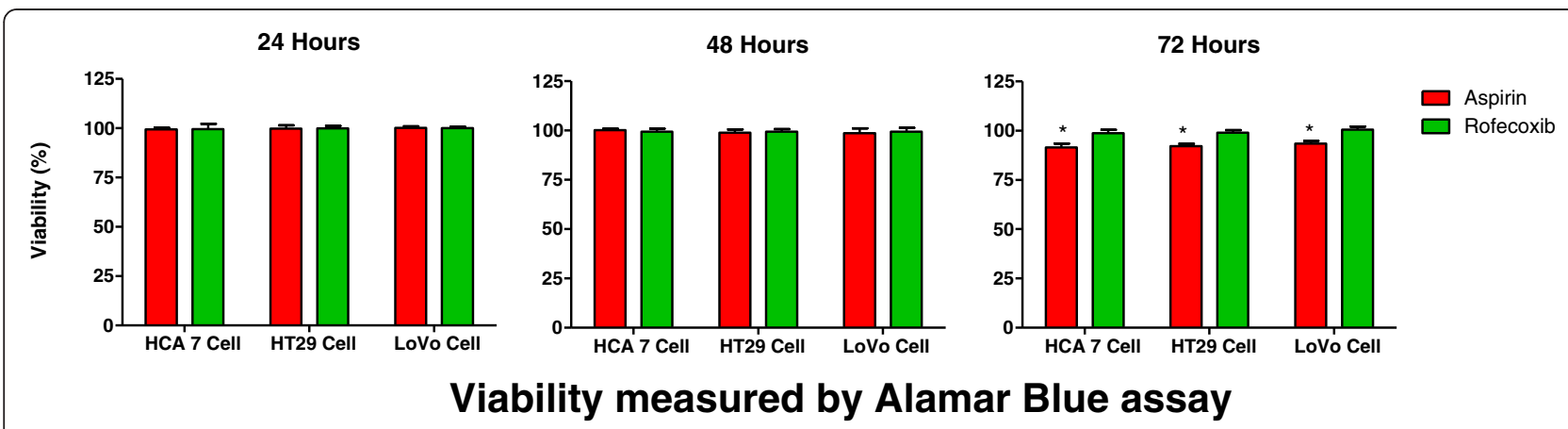

Figure 2 Effect of $1,000 \mu \mathrm{M}$ aspirin and $100 \mu \mathrm{M}$ rofecoxib on viability at 72 hours, relative to control. Results expressed as mean and standard deviation ( ${ }^{*} P<0.05$ ).

enzymes involved in the generation of prostaglandins and leukotrienes. In particular, COX-2 expression is upregulated in CRC and NSAIDs may reverse the carcinogenic process by inhibiting this enzyme. Recent studies also have shown that 5-LOX is expressed in colorectal adenocarcinomas and elevated expression of this enzyme appears to correlate with tumor aggressiveness [20], although the exact mechanism remains incompletely understood. The 5-LOX product leukotriene $\mathrm{B} 4$ is shown to promote colorectal cancer in an experimental model [35]. It seems likely, however, that COX-2 and 5-LOX represent an integrated system with a common substrate that regulates the proliferative, metastatic and pro-angiogenic potential of cancer cells. Both enzymes induce cell cycle progression and block apoptosis, enhance chemoresistance, and stimulate angiogenesis, with one convergent target on vascular endothelial growth factor (VEGF) expression and release [36].

COX and 5-LOX are frequently co-expressed, and inhibition of a single pathway may shunt arachidonic acid metabolism towards the alternative enzyme. The striking similarities between their biological functions suggest that molecules that equally block both COX-2 and 5-LOX may represent a novel and promising alternative in colon cancer treatment. In support of this mechanism, studies have shown that dual inhibition of COX-2 and 5-LOX have additive anti-cancer effects when compared to inhibition by either enzyme alone [37].

Whereas 5-LOX is universally expressed by all epithelial cancer cell lines COX-2 expression is variable [38]. The proposed shunting mechanism requires the expression of both enzymes. We intended to investigate that this phenomenon of shunting was not due to COX-2 independent process. Therefore, we used three cancer cell lines with differential COX-2 expression and activity to assess the shunting mechanism. HCA7 cells express active COX-2, HT29 cells express an enzymatically inactive variant [31] and LoVo cells do not express COX-2; all express 5-LOX. We found that HCA7 cells produced excess $\mathrm{PGE}_{2}$ by overexpressed COX-2, which was significantly reduced following aspirin and rofecoxib treatment. We observed, that in HCA7 cells, aspirin and rofecoxib treatment caused a reciprocal increase in $\mathrm{LTB}_{4}$ secretion. These results confirm the shunting hypothesis. In HT29 and LoVo cells with inactive and absent COX2 expression $\mathrm{LTB}_{4}$ secretion was not affected by COX-2 inhibition.

We next wanted to assess the anti-carcinogenic potential of an NSAID. Aspirin treatment did not induce significant anti-carcinogenic effect for up to 48 hours. Only at 72 hours did $1000 \mu \mathrm{M}$ aspirin cause a significant anticancer effect. Rofecoxib exhibited no anti-cancer effect at all times tested. The level of COX-2 expression of the cell did not have any impact on the anti-carcinogenic effects of NSAID. In COX-2 expressing cells, inhibition of COX-2 caused shunting of AA to the 5-LOX pathway resulting in carcinogenic $\mathrm{LTB}_{4}$ production. An increase in $\mathrm{LTB}_{4}$ antagonizes the anti-carcinogenic effect caused by a reduction in prostaglandin synthesis. In cells with inactive and absent COX-2 expression, COX-2 inhibition is unlikely to affect its growth. These observations suggest at least partially the existence of a shunting mechanism as well as COX-2 independent effects, and may underscore the importance of simultaneous inhibition of leukotriene production. Activity solely targeting the COX enzymes may be insufficient, possibly contributing to the previous conflicting results in this field [39].

The centrality of COX-2 in the anti-neoplastic actions of NSAIDs has also been questioned; for example, studies have demonstrated that replacement of prostaglandins fails to reverse their anti-cancer effects [40]. Additionally, sulindac is a pro-drug that is converted in vivo into its active sulfide and sulfone metabolites. Both of these metabolites inhibit colon cancer cell growth although only the sulfide inhibits prostaglandin synthesis. Finally, NSAIDs can induce apoptosis in HCT-15 cells, which lack COX transcripts [41]. All HCT-15 cells lack COX transcript. 


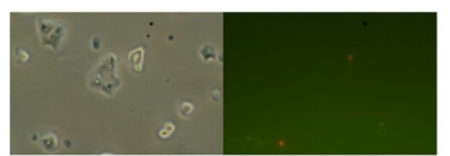

HCA 7 Cells

DMSO treatment

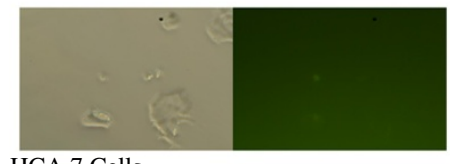

HCA 7 Cells

TRIS treatment

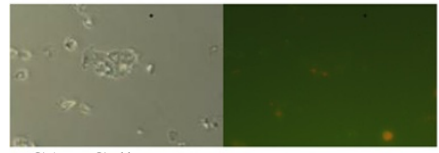

HCA 7 Cells

100 microM Rofecoxib treatment

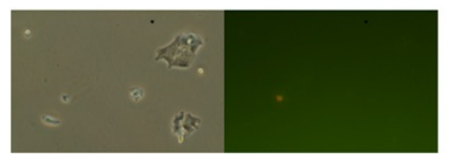

HCA 7 Cells

1000 microM Aspirin treatment

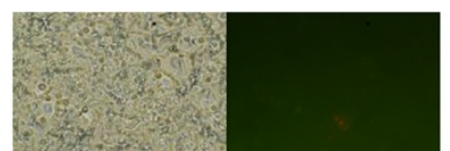

HT29 Cells

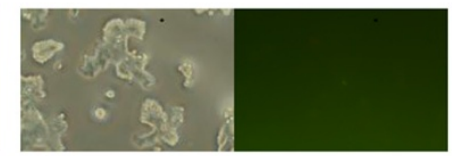

HT29 Cells

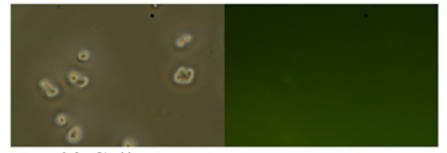

HT29 Cells

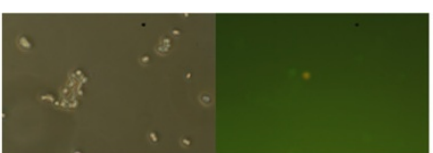

LoVo cells

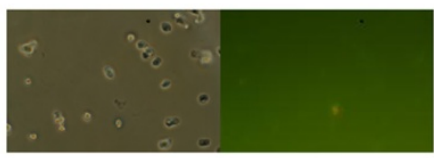

LoVo cells

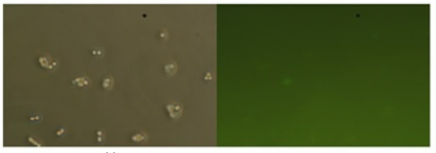

LoVo cells

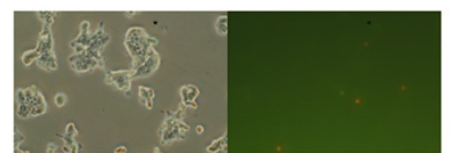

HT29 Cells

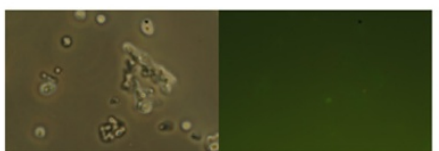

LoVo cells

A Apoptosis measured by Annexin V-Propidium Iodide staining
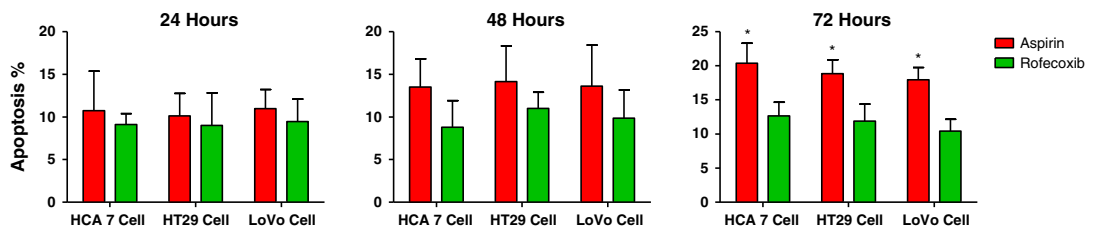

B Apoptosis percentage with 1000 microM aspirin and 100 microM rofecoxib
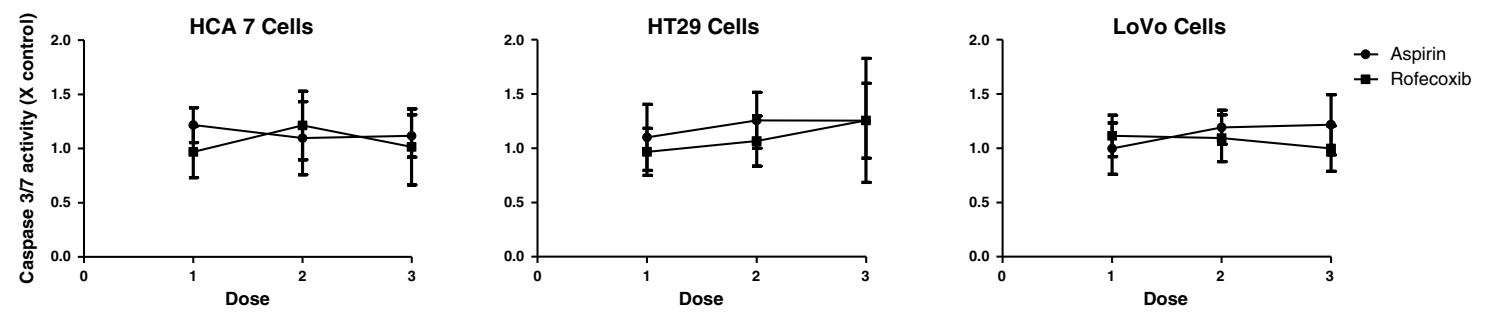

12 hours
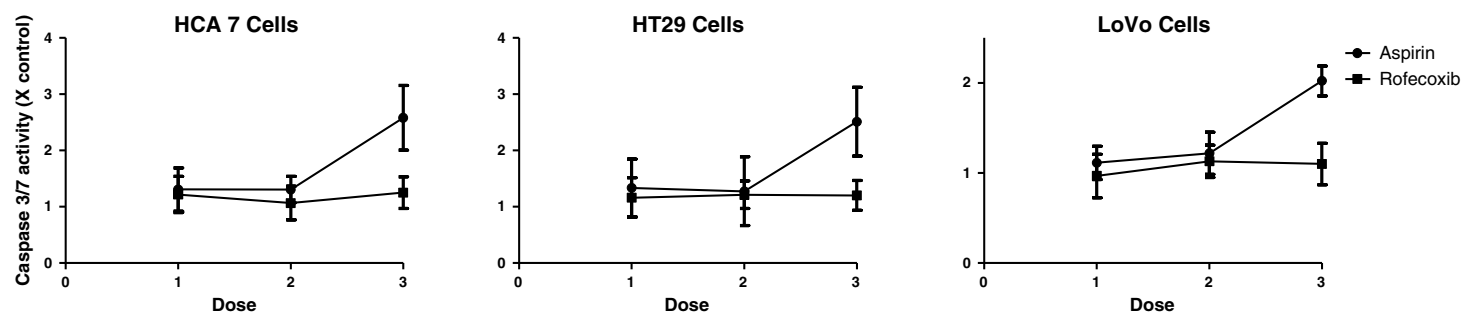

48 hours

C Caspase 3/7 activation following aspirin and rofecoxib treatment

Figure 3 (See legend on next page.) 
(See figure on previous page.)

Figure 3 Effects of 1,000 $\mu \mathrm{M}$ aspirin and $100 \mu \mathrm{M}$ rofecoxib on apoptosis. Representative images from light microscopy and immunofluorescence (demonstrating propidium iodide and annexin- $V$ staining) of HCA 7, HT29 and LoVo cells with no agent (control containing DMSO and TRIS), rofecoxib and aspirin (A). The apoptosis of cells is shown as percentage at 24, 48 and 72 hours by $1000 \mu \mathrm{M}$ aspirin, $100 \mu \mathrm{M}$ rofecoxib. Results are expressed as mean percentage of apoptosis $+/-$ SD $(* P<0.05)($ B). Caspase-3/7 activation relative to control at 12 and 48 hours. Mean and standard deviations of triplicate cultures shown (C).

\section{Conclusion}

This study confirms the process of shunting of arachidonic acid metabolism between the COX and 5-LOX pathways in the presence of inhibition of one of these enzymes. The shunting mechanism may explain the failure of COX-2 inhibitors to cause significant anti-carcinogenic effect. The observed in vitro effects should be reproduced in an animal model to provide evidence for the role of the shunting mechanism in vivo. Intervention that inhibits both the COX-2 pathway and the 5-LOX pathway will prove to be an effective anti-carcinogenic agent.

\section{Abbreviations}

AA: arachidonic acid; COX: cyclooxygenase; CRC: colorectal cancer; dsDNA: double-stranded DNA; ELISA: enzyme-linked immunosorbent assay; $\mathrm{LTB}_{4}$ : leukotriene $\mathrm{B}_{4}$; NSAIDs: non-steroidal anti-inflammatory drugs; $\mathrm{PGE}_{2}$ : prostaglandin $\mathrm{E}_{2}$; VEGF: vascular endothelial growth factor; 5-LOX: 5-lipoxygenase.

\section{Competing interests}

The authors declare that they have no competing interests.

\section{Authors' contributions}

RG contributed in conception, carried out experimental assays, acquisition of data,analysis, interpretation of data and in preparing the manuscript. DJBM involved in statistical analysis and drafting the manuscript. KS contributed in conception, design, experimental assay and interpretation of data and statistical analysis. MW contributed in conception, design and interpretation of the data. AS contribution includes conception, design, in carrying out experimental assay and interpretation of the data. All authors read and approved the final manuscript.

\section{Acknowledgements}

The authors thank Merck Sharp \& Dohme Inc. for provision of rofecoxib.

\section{Author details}

${ }^{1}$ Division of Surgery and Interventional Science, University College London, Rowland Hill Street, London NW3 2PF, UK. ${ }^{2}$ Centre for Molecular Medicine, University College London, 5 University Street, London WC1E 6JF, UK.

Received: 12 May 2012 Accepted: 10 September 2012

Published: 26 September 2012

\section{References}

1. Hamilton SR: The adenoma-adenocarcinoma sequence in the large bowel: variations on a theme. J Cell Biochem 1992, Suppl. 16G:41-46.

2. Doll R, Peto R: The causes of cancer: quantitative estimates of avoidable risks of cancer in the United States today. J Natl Cancer Inst 1981, 66:1191-1308

3. van Duijnhoven FJ, Bueno-De-Mesquita HB, Ferrari P, Jenab M, Boshuizen $\mathrm{HC}$, Ros MM, et al: Fruit, vegetables, and colorectal cancer risk: the European Prospective Investigation into Cancer and Nutrition. Am J Clin Nutr 2009, 89:1441-1452.

4. Terhaar Sive Droste JS, Tuynman JB, Van Dullemen HM, Mulder CJ: Chemoprevention for colon cancer: new opportunities, fact or fiction? Scand J Gastroenterol 2006, Suppl 158:158-164.
5. Lamprecht SA, Lipkin M: Chemoprevention of colon cancer by calcium, vitamin D and folate: molecular mechanisms. Nat Rev Cancer 2003, 3:601-614.

6. Pardi DS, Loftus EV Jr: Kremers WK, Keach J, Lindor KD: Ursodeoxycholic acid as a chemopreventive agent in patients with ulcerative colitis and primary sclerosing cholangitis. Gastroenterology 2003,

124:889-893.

7. Taylor ML, Wells BJ, Smolak MJ: Statins and cancer: a meta-analysis of case- control studies. Eur J Cancer Prev 2008, 17:259-268.

8. Krishnamoorthy S, Honn KV: Eicosanoids in tumor progression and metastasis. Subcell Biochem 2008, 49:145-168.

9. De Vries CE, van Noorden CJ: Effects of dietary fatty acid composition on tumor growth and metastasis. Anticancer Res 1992, 12:1513-1522.

10. Claria J: Regulation of cell proliferation and apoptosis by bioactive lipid mediators. Recent Pat Anticancer Drug Discov 2006, 1:369-382.

11. Smith WL, DeWitt DL, Garavito RM: Cyclooxygenases: structural, cellular, and molecular biology. Annu Rev Biochem 2000, 69:145-182.

12. Sano H, Kawahito Y, Wilder RL, Hashiramoto A, Mukai S, Asai K, Kimura S, Kato $\mathrm{H}$, Kondo M, Hla T: Expression of cyclooxygenase-1 and -2 in human colorectal cancer. Cancer Res 1995, 55:3785-3789.

13. Rigas B, Goldman IS, Levine L: Altered eicosanoid levels in human colon cancer. J Lab Clin Med 1993, 122:518-523.

14. Sun Y, Tang XM, Half E, Kuo MT, Sinicrope FA: Cyclooxygenase-2 overexpression reduces apoptotic susceptibility by inhibiting the cytochrome c-dependent apoptotic pathway in human colon cancer cells. Cancer Res 2002, 62:6323-6328.

15. Tang X, Sun YJ, Half E, Kuo MT, Sinicrope F: Cyclooxygenase-2 overexpression inhibits death receptor 5 expression and confers resistance to tumor necrosis factor-related apoptosis-inducing ligand-induced apoptosis in human colon cancer cells. Cancer Res 2002, 62:4903-4908.

16. Chulada PC, Thompson MB, Mahler JF, Doyle CM, Gaul BW, Lee C, Tiano HF, Morham SG, Smithies O, Langenbach R: Genetic disruption of Ptgs-1, as well as Ptgs-2, reduces intestinal tumorigenesis in Min mice. Cancer Res 2000, 60:4705-4708.

17. Prescott SM, Fitzpatrick FA: Cyclooxygenase-2 and carcinogenesis. Biochim Biophys Acta 2000, 1470:M69-M78.

18. Saini MK, Sharma P, Kaur J, Sanyal SN: The cyclooxygenase-2 inhibitor etoricoxib is a potent chemopreventive agent of colon carcinogenesis in the rat model. J Environ Pathol Toxicol Oncol 2009, 28:39-46.

19. Wang $L$, Chen W, Xie $X$, He $Y$, Bai $X$ : Celecoxib inhibits tumor growth and angiogenesis in an orthotopic implantation tumor model of human colon cancer. Exp Oncol 2008, 30:42-51.

20. Soumaoro LT, lida S, Uetake H, Ishiguro M, Takagi Y, Higuchi T, Yasuno M, Enomoto M, Sugihara K: Expression of 5-lipoxygenase in human colorectal cancer. World J Gastroenterol 2006, 12:6355-6360.

21. Melstrom LG, Bentrem DJ, Salabat MR, Kennedy TJ, Ding XZ, Strouch M, Rao SM, Witt RC, Ternent CA, Talamonti MS, Bell RH, Adrian TA: Overexpression of 5-lipoxygenase in colon polyps and cancer and the effect of 5-LOX inhibitors in vitro and in a murine model. Clin Cancer Res 2008, 14:6525-6530.

22. Park SW, Heo DS, Sung MW: The shunting of arachidonic acid metabolism to 5-lipoxygenase and cytochrome p450 epoxygenase antagonizes the anti-cancer effect of cyclooxygenase-2 inhibition in head and neck cancer cells. Cell Oncol (Dordr) 2012, 35:1-8.

23. Sanchez-Borges M, Capriles-Hulett A, Caballero-Fonseca F: NSAID-induced urticaria and angioedema: a reappraisal of its clinical management. Am J Clin Dermatol 2002, 3:599-607.

24. Labayle D, Fischer D, Vielh P, Drouhin F, Pariente A, Bories C, et al: Sulindac causes regression of rectal polyps in familial adenomatous polyposis. Gastroenterology 1991, 101:635-639. 
25. Vinogradova Y, Hippisley-Cox J, Coupland C, Logan RF: Risk of colorectal cancer in patients prescribed statins, nonsteroidal anti-inflammatory drugs, and cyclooxygenase-2 inhibitors: nested case- control study. Gastroenterology 2007, 133:393-402

26. Trujillo MA, Garewal HS, Sampliner RE: Nonsteroidal antiinflammatory agents in chemoprevention of colorectal cancer. At what cost? Dig Dis Sci 1994, 39:2260-2266.

27. Kerr DJ, Dunn JA, Langman MJ, Smith JL, Midgley RS, Stanley A, Stokes JC, Julier P, Iveson C, Durvuri R, McConkey CC, VICTOR Trial Group: Rofecoxib and cardiovascular adverse events in adjuvant treatment of colorectal cancer. N Engl J Med 2007, 357:360-369.

28. Schiffmann S, Maier TJ, Wobst I, Janssen A, Corban-Wilhelm H, Angioni C, Geisslinger G, Grösch S: The anti-proliferative potency of celecoxib is not a class effect of coxibs. Biochem Pharmacol 2008, 76:179-187.

29. Wobst I, Schiffmann S, Birod K, Maier TJ, Schmidt R, Angioni C, Geisslinger G, Grösch S: Dimethylcelecoxib inhibits prostaglandin E2 production. Biochem Pharmacol 2008, 76:62-69.

30. Ma D, Liu M, Wang AP, Yang H: Cycloxygenase-2 is essential for the survival and proliferation of gastric cancer cells. Cell Biochem Biophys 2011, 61:637-641.

31. Hsi LC, Baek SJ, Eling TE: Lack of cyclooxygenase-2 activity in HT-29 human colorectal carcinoma cells. Exp Cell Res 2000, 256:563-570.

32. Tavolari S, Bonafe M, Marini M, Ferreri C, Bartolini G, Brighenti E, Manara S, Tomasi V, Laufer S, Guarnieri T: Licofelone, a dual COX/5-LOX inhibitor, induces apoptosis in HCA-7 colon cancer cells through the mitochondrial pathway independently from its ability to affect the arachidonic acid cascade. Carcinogenesis 2008, 29:371-380.

33. Kannan RY, Salacinski HJ, Sales KM, Butler PE, Seifalian AM: The endothelialization of polyhedral oligomeric silsesquioxane nanocomposites: an in vitro study. Cell Biochem Biophys 2006, 45:129-136.

34. Federico A, Morgillo F, Tuccillo C, Ciardiello F, Loguercio C: Chronic inflammation and oxidative stress in human carcinogenesis. Int $\mathrm{J}$ Cancer 2007, 121:2381-2386.

35. Gao P, Guan L, Zheng J: Role of leukotriene B4 in celecoxib-mediated anticancer effect. Biochem Biophys Res Commun 2010, 402:308-311.

36. Romano M, Claria J: Cyclooxygenase-2 and 5-lipoxygenase converging functions on cell proliferation and tumor angiogenesis: implications for cancer therapy. FASEB J 2003, 17:1986-1995.

37. Ye YN, Wu WK, Shin VY, Bruce IC, Wong BC, Cho CH: Dual inhibition of 5-LOX and COX-2 suppresses colon cancer formation promoted by cigarette smoke. Carcinogenesis 2005, 26:827-834.

38. Hong SH, Avis I, Vos MD, Martinez A, Treston AM, Mulshine JL: Relationship of arachidonic acid metabolizing enzyme expression in epithelial cancer cell lines to the growth effect of selective biochemical inhibitors. Cancer Res 1999, 59:2223-2228.

39. Yamazaki R, Kusunoki N, Matsuzaki T, Hashimoto S, Kawai S: Selective cyclooxygenase-2 inhibitors show a differential ability to inhibit proliferation and induce apoptosis of colon adenocarcinoma cells. FEBS Lett 2002, 531:278-284.

40. Hanif R, Pittas A, Feng Y, Koutsos MI, Qiao L, Staiano-Coico L, Shiff SI, Rigas B: Effects of nonsteroidal anti-inflammatory drugs on proliferation and on induction of apoptosis in colon cancer cells by a prostaglandinindependent pathway. Biochem Pharmacol 1996, 52:237-245.

41. Rice PL, Kelloff J, Sullivan H, Driggers LJ, Beard KS, Kuwada S, Piazza G, Ahnen DJ: Sulindac metabolites induce caspase- and proteasomedependent degradation of beta-catenin protein in human colon cancer cells. Mol Cancer Ther 2003, 2:885-892.

doi:10.1186/1477-7819-10-200

Cite this article as: Ganesh et al: Cyclooxygenase/lipoxygenase shunting lowers the anti-cancer effect of cyclooxygenase-2 inhibition in colorectal cancer cells. World Journal of Surgical Oncology 2012 10:200

\section{Submit your next manuscript to BioMed Central and take full advantage of:}

- Convenient online submission

- Thorough peer review

- No space constraints or color figure charges

- Immediate publication on acceptance

- Inclusion in PubMed, CAS, Scopus and Google Scholar

- Research which is freely available for redistribution

Submit your manuscript at www.biomedcentral.com/submit
C Biomed Central 